\title{
Identification of toxigenic Microcystis strains after incidents of wild animal mortalities in the Kruger National Park, South Africa
}

\author{
Paul J. Oberholster ${ }^{\mathrm{a}, *}$, Jan G. Myburgh ${ }^{\mathrm{b}}$, Danny Govender ${ }^{\mathrm{c}}$, Roy Bengis ${ }^{\mathrm{d}}$, Anna-Maria Botha ${ }^{\mathrm{e}}$ \\ a CSIR Natural Resources and the Environment, P.O. Box 395, Pretoria 0001, South Africa \\ b Department of Paraclinical Sciences, Faculty of Veterinary Science, University of Pretoria, P/Bag X04, Onderstepoort 0110, South Africa \\ c South African National Parks, Veterinary Wildlife Services, P/Bag X402, Skukuza 1350, South Africa \\ d State Veterinary Investigation Center, P.O. Box 12, Skukuza 1350, Kruger National Park, South Africa \\ e Department of Genetics, University of Pretoria, Hillcrest, Pretoria 0002, South Africa
}

\section{A R T I C L E I N F O}

Article history:

Received 6 June 2008

Received in revised form

22 December 2008

Accepted 24 December 2008

Keywords:

Eutrophication

Wild animal bio-intoxication

Megaherbivores

mcy Gene cluster

Conservation areas

\begin{abstract}
A B S T R A C T
The eutrophic process potentially caused by a high urine and faecal load resulting from an unusually high hippopotamus (Hippopotamus amphibious) density in the Nhlanganzwane Dam, Kruger National Park, South Africa, triggered a chain of events characterised by an increase in the growth of primary producers (Microcystis aeruginosa). This increase in $M$. aeruginosa biomass was followed by biointoxication incidents in wild animals. In this study, we determine if a M. aeruginosa bloom with a total microcystin level of $23,718 \mu \mathrm{gl}^{-1}$ have been responsible for mortalities of megaherbivores in the Nhlanganzwane Dam. We further use microcystin molecular markers derived from the mcy gene cluster to identify potentially toxigenic environmental Microcystis strains in the dam during the occurrence of animal intoxications. The estimated total microcystin-LR daily intake by an adult male white rhinoceros (Ceratotherium simum) from cyanobacterial-contaminated water of the dam during the toxic event was an order of magnitude higher $\left(754.29 \mu \mathrm{g} \mathrm{kg}^{-1} \mathrm{bw}\right)$ in comparison with the lowest observed adverse effecting level (LOAEL) value measured for pigs in a previous study by other authors. In this study the presence of toxic cyanobacterial strains was confirmed with the use of molecular markers that detected the presence of the mcy gene cluster responsible for the production of toxin by M. aeruginosa.
\end{abstract}

(c) 2009 Elsevier Inc. All rights reserved.

\section{Introduction}

Eutrophication is the natural ageing process of lakes. It is characterized by a geologically slow shift from in-lake biological production driven by allochthonous loading of nutrients, to production driven by autochthonous processes. This typically slow process over centuries can be greatly accelerated to within decades by human intervention in the natural biogeochemical cycling of nutrients within a watershed (Rast and Thornton, 1996). This eutrophication is mainly caused by the addition of nutrients from human activities, called in this context, anthropogenic eutrophication. The phenomenon is generally a consequence of intensive agricultural and industrial activities and the development of large sewage systems associated with large metropolitan areas (Pitois et al., 2001). Although there are a few previous studies that indicate eutrophication (over-enrichment) as a direct consequence of resident animals, fish and birds in freshwater bodies (Bomchul et al., 2001; Oberholster and Botha, 2007), little

\footnotetext{
* Corresponding author. Fax: +27124202954.

E-mail address: poberholster@csir.co.za (P.J. Oberholster).
}

is known about eutrophication as a result of megaherbivores on lake ecosystems. In many cases the direct consequences of eutrophication are the excessive growth of autotrophic organisms. In standing waters this manifests in blooms of generally undesirable cyanobacteria. Some species of cyanobacteria may produce substances that are highly toxic. The identification of a cyanobacterial genus by microscopic morphology does not indicate its potential for toxin production. Different strains of one species can be morphologically identical but differ in toxigenicity. For example, Microcystis aeruginosa which is the most abundant toxic cyanobacterial genus in South Africa may contain both toxic and non-toxic strains (Meissner et al., 1996; Bolch et al., 1997).

The Kruger National Park is one of the largest conservation areas in Africa and covers $19,485 \mathrm{~km}^{2}$ on South Africa's eastern borders with Mozambique (Fig. 1). Its perimeters were entirely fenced from 1974 to 1993, when sections of the western fence bordering private wildlife reserves were removed. Megaherbivores are an important component of the fauna and include the elephant (Loxodonta africana), white rhinoceros (Ceratotherium simum) and hippopotamus (Hippopotamus amphibius). Annual rainfall varies from $750 \mathrm{~mm}$ in the south-west to $450 \mathrm{~mm}$ in the 


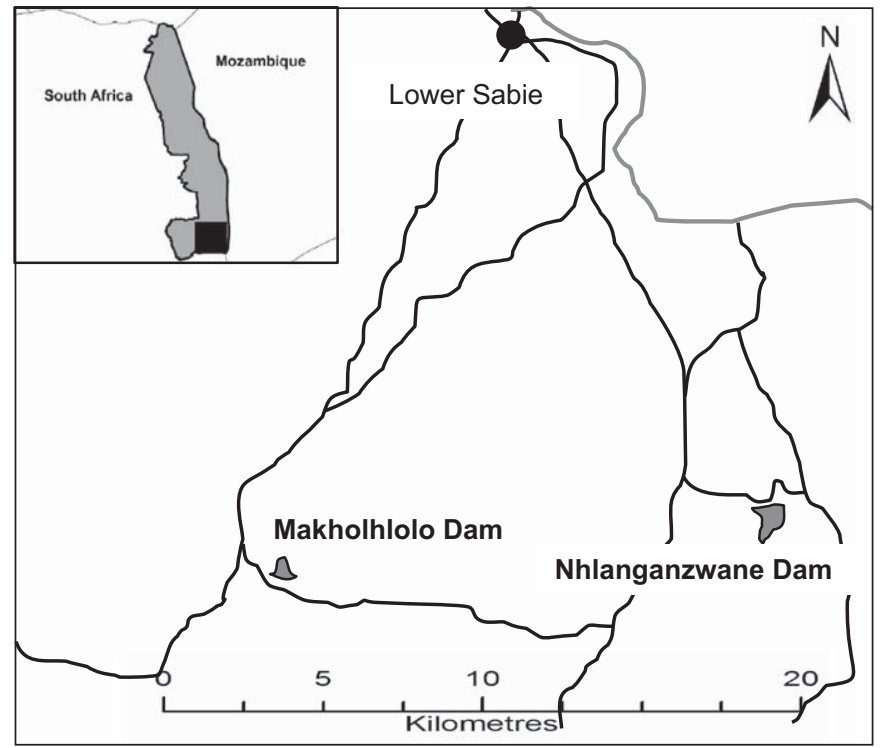

Fig. 1. Map of the Kruger National Park with cluster of two point source incidents of wildlife mortalities.

north-east, with $80 \%$ received during the summer months of October to March (Eckhardt et al., 2000).

With the establishment of the Kruger National Park in 1898, animals concentrated during the dry season around five perennial rivers (Pienaar, 1970). Between these rivers only a few natural perennial water sources existed and most of the water sources were unreliable and depended on seasonal rainfall events (Pienaar, 1970). In the early 1930s, the Kruger National Park water stabilisation programme started, but gained particular momentum in the 1960s after fencing of the western boundary of the park, which blocked the migration routes of certain herbivores to this area that previously acted as dry season grazing. Until the 1980s more than 300 boreholes were drilled, 50 earth dams were constructed and various seasonal and perennial rivers dammed as part of the water provision programme to ensure all year round reliable surface water throughout the park (Gaylard et al., 2003).

During the autumn and early winter of 2005 rangers of the Kruger National Park found several carcasses in the region of one of these artificial water points, namely the Nhlanganzwane Dam that is situated in the extreme south eastern corner of the Kruger National Park, to the south of Lower Sabie restcamp (Fig. 1). Blood smears sent to the State Veterinary laboratory at Skukuza were negative for anthrax. Due to the decomposed state of the carcasses, it was not possible to perform necropsies, and the cause of death could not be determined. After discovery of a fresh zebra carcass in May 2005, a detailed necropsy was performed and a full range of laboratory tests were conducted by the State Veterinary Services and the Onderstepoort Veterinary Institute. The microscopic lesions in the liver as well as formation of intracytoplasmic eosinophilic globules in some hepatocytes and proliferation and accumulation of a lipofuscinous pigment in Kuffer cells especially in the centrilobular areas were compatible with a diagnosis of Microcystis intoxication (Bengis et al., 2008). Mouse toxicity tests were also strongly positive. During the time of the discovery of the carcasses, water levels at all the dams in the region were unusually low and approximately 100 hippopotami inhabited the Nhlanganzwane Dam. The large density of hippopotamus in the dam may have resulted in eutrophication which most probably has given rise to the visible cyanobacterial bloom. A total of 52 carcasses were detected from February to July 2005 consisting of 7 white rhinoceros, 2 lions, 2 cheetahs,
9 zebras, 23 wildebeest, 1 hippopotamus, 1 giraffe, 5 buffalo, 1 warthog and 1 kudu. Mortalities decreased to zero after July 2005 when the overgrazed area surrounding Nhlanganzwane Dam was subject to a low intensity accidental veldt fire. This resource depletion resulted in the dispersal of herbivores from the area, including the hippopotamus population, which dispersed to the Sabie and Crocodile Rivers. Two years later, in June 2007, mortalities of white rhinoceros, zebras and wildebeest where again reported from the area of the Nhlanganzwane Dam. Microscopic lesions in the livers of these dead animals were compatible with a diagnosis of Microcystis intoxication (Bengis et al., 2008). Once again there was a visible cyanobacterial bloom as well as a large resident hippopotamus population in the dam.

The objectives of this study were (1) to use PCR assays to assess the presence of possible toxigenic strains of $M$. aeruginosa Kützing ex Lemmermann in Nhlanganzwane Dam in the Kruger National Park, around which two mortality clusters in wild animals, associated with cyanobacterial intoxication, occurred in the dry seasons of 2005 and 2007. (2) To unravel the animal mortalities in the region of this dam, we investigate some limnological conditions of the dam at the time of the intoxication event, as well as the role played by megaherbivores associated with the dam.

\section{Materials and methods}

\subsection{Sampling protocol and enumeration of phytoplankton species}

One sampling trip was undertaken in July 2007 during the occurrence of the cyanobacterial intoxication event. Sampling was performed in triplicate with $200 \mathrm{ml}$ polyethylene bottles at three different sampling sites by scooping up surface water $( \pm 10 \mathrm{~cm}$ depth) within the littoral zone of the Nhlanganzwane Dam. Sampling were conducted in areas where cyanobacteria cells accumulated (surface film $\pm 4 \mathrm{~cm}$ thick) as well as in the littoral zone of the Makhohlolo Dam that was uninhabited by hippopotami and contained very low concentrations of cyanobacterial cells $\left(2.3 \times 10^{2}\right.$ cells $\left.\mathrm{ml}^{-1}\right)$ and a low water level that was not suitable for hippopotami. The latter served as a control for this study and was within the region of the Nhlanganzwane Dam. Water samples were transferred from the field to the laboratory in a dark coolbox. Phytoplankton species composition and community structure were assessed from 10-ml aliquots sampled from 200-ml water samples after it was fixed with Lugol's solution. Colonies of Microcystis were disintegrated by ultrasonication prior to counting ( 40 impulses/s over $4 \mathrm{~min}$ for a 10-ml sample) (Kurmayer et al., 2003). Phytoplankton cells were identified and counted from transects in a Sedgewick-Rafter sedimentation chamber with an inverted microscope. Identification and counting of phytoplankton were carried out according to procedures outlined by Lund et al. (1958) and Padisak (1993). While general algal species identification was carried out using Wehr and Sheath (2003).

\subsection{Pigment and physical/chemical determination}

Physical/chemical analyses were conducted from subsamples of the triplicate $200 \mathrm{ml}$ polyethylene bottles. These $200 \mathrm{ml}$ surface water samples were taken at a depth of $10 \mathrm{~cm}$ at the same three sampling sites in the littoral zone of both dams. Chlorophyll- $a$ was assessed from a 50-ml aliquots sampled from 200-ml surface water samples. Chlorophyll- $a$ was .extracted from lyophilized GF filters $(20 \mu \mathrm{m})$ and kept in $\mathrm{N}, \mathrm{N}$-dimethylformamide for $2 \mathrm{~h}$ at room temperature. Chlorophyll- $a$ was then measured photospectrometrically at 647 and $664 \mathrm{~nm}$ according to the calculations of Porra et al. (1989). Nutrient concentrations were analyzed from 100-ml aliquots sampled from 200-ml surface water samples using the American Public Health Association, American Water Work Association, and Water Pollution Control Federation (1998) classical spectophotometric methods. Temperature, dissolved oxygen (DO) and conductivity of the water column were measured at a depth of $10 \mathrm{~cm}$ at all three sampling sites in both dams with a $\mathrm{Hach}^{\mathrm{TM}}$ sension 156 portable multiparameter (Loveland, CO, USA). To determine the trophic state of the Nhlanganzwane and Makhohlolo Dams during the poisoning incidence in 2007, inorganic nitrogen (IN), total nitrogen (TN), total phosphorus (TP), chlorophyll- $a$ as well as the TN:TP ratio were used following the trophic state index of Vollenweider (1968) and Forsberg and Ryding (1980).

We obtained mean monthly air temperatures and rainfall patterns of 2005 and 2007, from stations within or near the Southern region of the Kruger National Park from the South African Weather Bureau, and amalgamated these to derive the mean annual temperature regime for the region. 


\subsection{Cyanobacterial reference strain culturing}

The toxic, axenic M. aeruginosa strain PCC 7806, obtained from the Institute Pasteur (PCC; Paris, France) was used in this study as reference strain. The Microcystis field strain was cultured in liquid BG-11 medium at $24^{\circ} \mathrm{C}$ under continuous illumination of approximately $60 \mu \mathrm{mol}$ photons (PAR) $\mathrm{m}^{-2} \mathrm{~s}^{-1}$. Light intensity was measured with a Cole Parmer Model DLM2 light meter (Vernon Hills, Illinois, USA) at a pH of 8.0 on a daily basis. All cultures were routinely screened for contamination by streaking samples on TYG agar and in TYG broth. Cells were harvested at late-exponential growth phase.

\subsection{Microcystin analysis}

For cyanotoxin analysis, a volume representing $50 \mathrm{mg}$ dry weight of the environmental strains biomass was filtered through glass fiber filters, air dried and stored in the dark at room temperature. Cyanotoxicity was determined with an enzyme-linked immunosorbent assay (ELISA), using a Quanti ${ }^{\mathrm{TM}}$ Kit for microcystins (EnviroLogix, USA). Results were obtained by reading the absorbance using a microtitre plate reader set (Thermo Labsystems, USA) a $450 \mathrm{~nm}$ within $30 \mathrm{~min}$ after the addition of the stop solution. It has been estimated that the average cellular microcystin-LR content for Microcystin aeruginosa in laboratory cultures is approximately $0.2 \mathrm{pg} /$ cell (range, $0.07-0.3 \mathrm{pg}$; Mole et al., 1997). On this basis, the total intracellular microcystin $\left(T_{\mathrm{cm}}\right)$ of the bloom was determined for the period of intoxication by animals using the following equations:

$T_{\mathrm{cm}}=I_{\mathrm{c}} \times C_{\mathrm{a}}$

where $I_{\mathrm{c}}$ is the average intracellular microcystin-LR (pg/cell) and $C_{\mathrm{a}}$ the cyanobacterial cell abundance (cells $\mathrm{ml}^{-1}$ ) of the bloom.

The daily total microcystin-LR intake $\left(D_{\mathrm{m}}\right)$ by different wild animals during the occurrence of intoxication event was determined by the following equations

$D_{\mathrm{m}}=\frac{T_{\mathrm{m}} \times W_{\mathrm{r}}+E_{\mathrm{m}}}{M_{\mathrm{bw}}}$

where $T_{\mathrm{m}}$ is the total intracellular microcystin-LR $\left(\mu \mathrm{gl}^{-1}\right), E_{\mathrm{m}}$ the total extracellular microcystin-LR $\left(\mu \mathrm{gl}^{-1}\right), W_{\mathrm{r}}$ the daily water requirements of a animal (litres) and $M_{\mathrm{bw}}$ the average mean body weight (kilogram).

\subsection{Assessing toxigenicity by PCR}

DNA was extracted from the environmental strains as well as from the reference strain PCC 7806 using DNAzol ${ }^{\mathbb{R}}$-Genomic DNA Isolation reagen following the manufacturers' procedures (Molecular Research Center, Inc., USA). PCR amplification was performed in a GeneAmp2400 thermocycler (Perkin-Elmer Cetus, Emeryville, California, USA). The thermal cycling protocol included an initial denaturation phase at $94{ }^{\circ} \mathrm{C}$ for $2 \mathrm{~min}$, followed by 35 cycles Each cycle began with $30 \mathrm{~s}$ at $96^{\circ} \mathrm{C}$ followed by $30 \mathrm{~s}$ at the annealing temperature at $T_{\mathrm{M}}{ }^{\circ} \mathrm{C}$ for the specific primer pairs (Quahid et al., 2004, 2005; Qberholster et al., 2006), and $30 \mathrm{~s}$ at $72^{\circ} \mathrm{C}$ for the elongation step. The PCR reaction was terminated by maintaining samples at $72{ }^{\circ} \mathrm{C}$ for $7 \mathrm{~min}$. The amplification reaction contained a $10 \times$ amplification buffer with $1.5 \mathrm{mM} \mathrm{MgCl}_{2}, 0.2 \mathrm{mM}$ dNTPs, 20 pmol of each primer and $1 \mathrm{U}$ Taq DNA polymerase, and 3-5 $\mathrm{ng}$ purified DNA in a final volume of $20 \mu$ l. Electrophoresis of the PCR products was carried out in $2 \%$ agarose gels in TAE buffer (0.04 M Tris-acetate-0.001 M EDTA [pH 8.0]), and the DNA was stained with ethidium bromide and visualized and photographed under UV transillumination.

\subsection{Data analysis}

In this study, results were recorded on standard Excel spreadsheets for data processing, and statistical analysis was performed using SYSTAT ${ }^{\mathbb{R}}$ 7.0.1 (SPSS Inc., 1997). Statistical differences were analyzed calculating Pearson correlation and a $t$ test using the Sigma Plot (Jandel Scientific) program. Values of $p \leqslant 0.05$ were regarded as significant

\section{Results}

\subsection{Species composition}

The surface water samples at the three sampling sites collected in July 2007 revealed a cyanobacterial abundance of $1.1 \times 10^{8}$ cells $\mathrm{ml}^{-1}$ with the occurrence of one cyanobacterial morphospecies M. aeruginosa (Wehr and Sheath, 2003) in the Nhlanganzwane Dam. In terms of abundance, the phytoplankton community in the
Nhlanganzwane Dam was dominated by the cyanobacteria M. aeruginosa, followed by Chlorophyceae (most abundant species: Scenedesmus armatus). Euglenophyceae (e.g. Phacus longicauda) occurred in very low numbers. The total number of phytoplankton species encounter in all samples combined were 16 species of which 9 species occurred in the Makhohlolo Dam.

\subsection{Physicochemical measurements}

The physicochemical conditions measured in the Nhanganzwane Dam in July 2007 were total nitrogen, inorganic nitrogen, total phosphorus, total microcystin, chlorophyll- $a$, dissolved oxygen and water temperature. Data measured in the Nhanganzwane Dam in July 2007 were the following: total nitrogen, $13,600 \mu \mathrm{gl}^{-1}$; inorganic nitrogen, $2171 \mu \mathrm{gl}^{-1}$; total phosphorus, $1210 \mu \mathrm{gl}^{-1}$; soluble reactive phosphorus, $129 \mu \mathrm{gl}^{-1}$; total microcystin level, 23,718 $\mathrm{gl}^{-1}$, chlorophyll-a, $580 \mu \mathrm{gl}^{-1}$, dissolved organic carbon, $6.1 \mathrm{mgl}^{-1}$, dissolved oxygen, $2.13 \mathrm{mgl}^{-1}$ and surface water temperature $22^{\circ} \mathrm{C}$. According to the near surface water average nutrient concentration index of Vollenweider (1968) and Forsberg and Ryding (1980) for classification of the trophic states of the dam during the time of the animal mortalities, the dam was hypertrophic in July 2007. A significant positive relationship $(r=0.98229 ; p \leqslant 0.02)$ between the high cyanobacterial cell abundance and high soluble reactive phosphorus concentration $\left(129 \mu \mathrm{gl}^{-1}\right)$ was observed. The soluble reactive phosphorus concentration in Nhlanganzwane Dam exceeded the level of $50 \mu \mathrm{gl}^{-1}$ considered conducive to cyanobacterial blooms (Wasson et al., 1996). The Makhohlolo Dam, on the other hand, had low total nitrogen $\left(660 \mu \mathrm{gl}^{-1}\right)$ and total phosphorus $\left(21 \mu \mathrm{gl}^{-1}\right)$ concentrations, indicating a mesotrophic system (Table 1 ). The average temperature range of the surface water in July 2007 was $20-22^{\circ} \mathrm{C}$. Rainfall data revealed a dryer winter season in 2005 than in 2007 with high air temperatures in both cases.

\section{Table 1}

Physicochemical measurements of raw surface water of the Nhanganzwane and Makhohlolo Dams in July $2007(n=1)$.

\begin{tabular}{lll}
\hline Physicochemical variables: & Nhanganzwane Dam & Makhohlolo Dam \\
\hline Total Nitrogen & $13,600 \mu \mathrm{gl}^{-1}$ & $660 \mu \mathrm{g} \mathrm{l}^{-1}$ \\
Inorganic nitrogen & $2171 \mu \mathrm{gl}^{-1}$ & $183 \mu \mathrm{gl}^{-1}$ \\
Total phosphorus & $1210 \mu \mathrm{gl}^{-1}$ & $22 \mu \mathrm{gl}^{-1}$ \\
Soluble reactive phosphorus & $129 \mu \mathrm{gl}^{-1}$ & $6.2 \mu \mathrm{gl}^{-1}$ \\
Total microcystin & $23,718 \mu \mathrm{gl}^{-1}$ & $0.317 \mu \mathrm{gl}^{-1}$ \\
Chlorophyll- $a$ & $580 \mu \mathrm{gl}^{-1}$ & $3.8 \mu \mathrm{gl}^{-1}$ \\
Dissolved oxygen & $2.13 \mathrm{mgl}^{-1}$ & $4.38 \mathrm{mg} \mathrm{l}^{-1}$ \\
Dissolved organic carbon & $6.1 \mathrm{mgl}^{-1}$ & $1.3 \mathrm{mg} \mathrm{l}^{-1}$ \\
\hline
\end{tabular}

The Nhanganzwane Dam was occupied by a large resident of hippopotamus population during this time.

Table 2

Estimated average daily intake of cellular microcystins by different herbivores at Nhlanganzwane Dam, July 2007.

\begin{tabular}{llll}
\hline Herbivores & $\begin{array}{l}\text { Mean } \\
\text { weight at } \\
\text { maturity } \\
\text { in kg }\end{array}$ & $\begin{array}{l}\text { Water } \\
\text { requirement } \\
\text { in litres per } \\
\text { day }\end{array}$ & $\begin{array}{l}\text { Average daily } \\
\text { microcystin-LR } \\
\text { intake } \\
\left(\mu \mathrm{gg}^{-1} \mathrm{~d}\right)\end{array}$ \\
\hline White rhinoceros male & 2100 & 72 & 754.29 \\
White rhinoceros female & 1600 & 72 & 990 \\
Zebra: Burchells & 240 & 12 & 1100 \\
Warthog & 30 & 3.5 & 2566.6 \\
Wildebeest: black & 160 & 7 & 962.5 \\
\hline
\end{tabular}




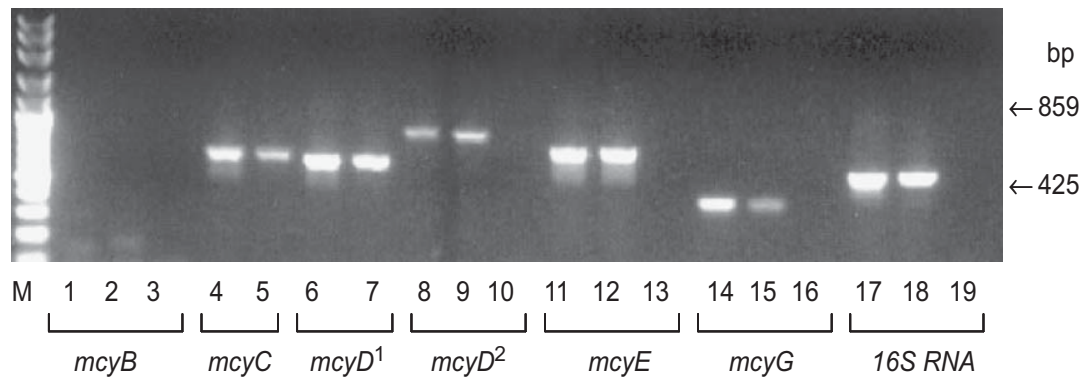



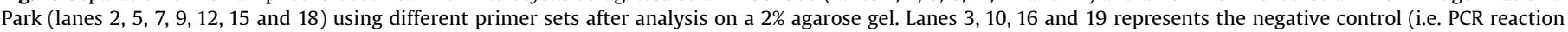
without genomic DNA template). $M=100 \mathrm{bp}$ ladder (O'RangeRular ${ }^{\mathrm{TM}} 100 \mathrm{bp}$ DNA Ladder).

\subsection{Microcystin analysis}

The total microcystin level determined in July 2007 by ELISA was $23,718 \mu \mathrm{g} \mathrm{l}^{-1}$ while the extracellular microcystin-LR level was $2.1 \mu \mathrm{gl}^{-1}$. To the author's knowledge, the microcystin level measured in the Nhlanganzwane Dam in July 2007 is one of the highest levels ever measured to date in South Africa. In a previous study on Hartbeespoort Dam (during the period August 2003 to May 2004) by the South African Department of Water Affairs and Forestry, the maximum total microcystin value recorded to date was $14,400 \mu \mathrm{gl}^{-1}$, while low levels of cyanobacteria toxins persist thought the year at levels above $10 \mu \mathrm{gl}^{-1}$ (Van Ginkel, 2004).

The microcystin levels measured in other dams within the region of the Nhlanganzwane Dam during the time of the animal mortalities in 2007 were much lower (Mpanama Dam, $0.581 \mu \mathrm{g}$ $\mathrm{I}^{-1}$ and Makhohlolo Dam, $0.317 \mu \mathrm{gl}^{-1}$ ). The possible daily total microcystin-LR intake per body weight calculated for different animals consuming the shallow surface mixed layer $(10 \mathrm{~cm}$ depth) of contaminated water from the Nhlanganzwane Dam during the period July 2007 were very high (Table 2.).

\subsection{Assessing toxigenicity by $P C R$}

The PCR products on the basis of the six mcy gene primers used, reveal the presence of the polyketide synthase genes (Fig. 2), which are ultimately responsible for the synthesis of the characteristic microcystin amino acid Adda (3-amino-9-methoxy-2,6,8-trimethyl-10 phenyldeca-4,6-dienoic acid), a 20-carbon amino acid that is important for the toxicity of microcystins (Harada et al., 1996). Measurement of the total microcystin level by ELISA confirms the presence of microcytin toxins in all the samples tested and was concurrent with the results obtained from the PCR analysis.

\section{Discussion}

The occurrence of the toxic bloom of $M$. aeruginosa and incidence of animal mortalities in 2007 permitted comparison of the dam conditions and identification of ecological drivers that promoted the occurrence of a toxic cyanobacterial bloom. Microscopic identification of the bloom composition revealed the dominance of cyanobacteria and the occurrence of very low numbers of other phytoplankton species. There are two plausible explanations for this phenomenon; firstly, $M$. aeruginosa blooms can reduce the growth of other phytoplankton because their surface habitat limits light transmission into the water column and allows them to out compete other phytoplankton that cannot tolerate the high light and the water temperatures at the surface (Robarts and Zohary, 1992). Secondly, the high suspended solids ( $112 \mathrm{mg} \mathrm{l}^{-1}$ ) in the water column and stratification generate an underwater light climate that favors cyanophytes like Microcystis (Dokulil and Teubner, 2000; Bonnet and Poulin, 2002).

The high level of inorganic nitrogen $\left(2171 \mu \mathrm{gl}^{-1}\right)$ in the upper water column is possibly the direct impact of urination and faecal eutrophication by the high density of Hippopotami that inhabited the dam during the time of the intoxication event in 2007. The release of nitrogen from the decaying dung and urine of the hippopotami, possibly supplied the cyanobacteria with a slow but steady supply of $\mathrm{NH}_{4}^{+}-\mathrm{N}$, sufficient for maximum growth and bloom formation. An increased of $\mathrm{NH}_{4}^{+}-\mathrm{N}$ availability can also stimulate buoyancy in cyanobacteria and might be a secondary effect related to the growth phase (Spencer and King, 1987). However, the levels of inorganic nitrogen $\left(183 \mu \mathrm{gl}^{-1}\right)$ in the Mpanama Dam during the time of the animal mortalities in 2007 were much lower than in the Nhlanganzwane Dam, possible due to the absence of Hippopotami because this dam was to shallow to support hippos. This in turn may have cause the nonappearance of a Microcystis bloom in the Mpanama Dam. The surface water temperature of $20-22{ }^{\circ} \mathrm{C}$ and the high levels of total microcystin $\left(23,718 \mu \mathrm{gl}^{-1}\right)$ is comparable with observations by Van der Westhuizen and Eloff (1985) in laboratory culture strains, which indicate the toxicity of $M$. aeruginosa grown at $20^{\circ} \mathrm{C}$ is much higher than that at 15,28 and $38^{\circ} \mathrm{C}$. However, Orr and Jones (1998) reported in their study a direct linear correlation between cell division and microcystin production rates in all microcystinproducing cyanobacteria regardless of the environmental factors that is limiting cell division.

In order to explain the mortalities of the white rhinoceroses, but not the hippopotami during July 2007, their association patterns with water were studied. Water intake by white rhinoceroses occurs mainly at night-time (Owen-Smith, 1973). During daylight hours, a higher photon irradiance allows Microcystis cells to accumulate carbohydrates. This increases their net cell density, and they lose buoyancy and sink, only to float up later to the surface due to the reduction of light and turgor pressure. In addition, under low light conditions (late afternoon), cyanobacteria increase their buoyancy by forming more gas vesicles and accumulate in high numbers in the surface water, since a linear relation between the loss of buoyancy and carbohydrate content and buoyancy state and the light dose received were reported for Microcystis cells by previous authors for both culture (Kromkamp and Mur, 1984) and in natural populations (Visser et al., 1996; Oberholster et al., 2005, 2006). As night falls Microcystis cells cannot change their buoyancy due to low light intensity and therefore stay in the surface water near shore where the white rhinoceroses drink. This phenomenon of vertical migration patterns by cyanobacteria colonies at night and early morning 
were previously observed in studies by Oberholster et al. (2006) and Pearson (1990).

Unlike white rhinoceroses, hippopotami have strong temporal and spatial constraints on their foraging behavior. Hippopotami are temporally contained in that they forage primarily at night (Laws, 1968). This is the time period when cyanobacterial cell concentrations are the highest in the surface water and exposure to cyanobacteria by oral ingestion is most likely. Although hippopotamus populations normally spend a large proportion of day time immersed in water (Schwarm et al., 2003) they congregate in deeper water where cyanobacteria colonies are suspended in the water column. Generally microcystin concentrations are much higher at sites where toxic cyanobacteria accumulate, rather than in the open water. The accumulation of cyanobacterial colonies is the result of their positive buoyancy and wind-driven hydrodynamics, with leeward shorelines and embankments being the likely sites for surface scum accumulation.

Furthermore, the common hippopotamus represents the largest extant terrestrial foregut fermenter (Owen-Smith, 1988). Their daily intake and gut capacity per body weight is lower than other megaherbivores of comparable size, which most likely stems from their very long ingesta retention times recorded by Foose (1982). Due to the tubular nature of the forestomach and the long ingesta retention time, cyanobacterial cells ingested while drinking or swimming have sufficient time to mix with digestible nutrient-fiber and general organic matter which could reduce the toxicity levels of the toxic Microcystis cells. The possible total average microcystin-LR daily intake for a male white rhinoceros, consuming contaminated cyanobacterial water from the Nhlanganzwane Dam in July 2007 was $754.29 \mu \mathrm{g} \mathrm{kg}^{-1}$ bw. In a previous study conducted by Falconer et al. (1994) they determine that the lowest observed adverse effecting level (LOAEL) of microcystin in pigs were $280 \mu \mathrm{g} \mathrm{kg}^{-1} \mathrm{bw}$, with general liver injury (evident from histopathology and changes in serum enzymes) occurring at two higher dose levels. Laboratory studies by Fawell et al. $(1994,1999)$ indicate that the lowest observed effecting level (LOEL) of microcystin-LR by oral route in mice was $\left(\mathrm{LD}_{50}\right) 5000 \mu \mathrm{g} \mathrm{kg}^{-1} \mathrm{bw}$. We assume from the above data in this study, that the high level of $23,718 \mu \mathrm{gl}^{-1}$ measured with ELISA as well as the microcystin LOAEL data established for pigs by Falconer et al. (1994), indicate that the possible cause of the mortalities of the white rhinoceroses, zebra, wildebeest and other species, in the region of the Nhlanganzwane Dam, was most likely due to acute rather than chronic exposure to microcystin toxins.

Although the mentioned microcystin intake value of different animals in this study is a (realistic) rough estimate, there are other factors that could have played a role e.g. the water intake of animal's increases during their gestation period. Hence, few studies of this nature exist and it is known that the water intake of cattle increases by about $50 \%$ in the last 4 months of their gestation period (Meyer et al., 1996). Furthermore, we speculated that the wild animals that died in July 2007 of cyanobacterial intoxication, has drunk dam water down wind to avoid the attention of predators. It is usually in these areas where cyanobacterial scum accumulates. In addition, Lopez Rodas and Costas (1999) found in their study that mice preferred to consume rather dense cultures of a toxic strain of $M$. aeruginosa than lowdensity cultures or clear water. They have confirmed their findings in the field with observations from several reservoirs in Spain.

A shortfall of this study however, was that only a single sampling trip was undertaken during the occurrence of the wild animal intoxications in July 2007, and we are aware that cyanobacterial blooms can vary substantially between seasons, weeks or even days. These variations might be caused by changes in species composition, production of different toxins with varying toxicity by one clone or other reasons influenced by environmental factors (Benndorf and Henning, 1989). However, the only time there is assessment of surface water in conservation areas like the Kruger National Park, is when there are deaths of wild animals. This is also a major problem when it comes to diagnosis of cyanobacterial poisoning in wildlife, since carcasses of these animals are usually found decomposed or partially consumed by scavengers. However, the detection of fresh animal carcasses in June 2007 made it possible to associate the Microcystis bloom with the wildlife mortalities.

In the present study, six mcy gene primers where used to help improve toxigenicity typing of $M$. aeruginosa strains, which is the dominant genus causing most cyanobacterial-related animal mortalities in South Africa (Oberholster et al., 2006). These six primers were selected, since in a previous study conducted on 12 dams by Botha and Oberholster (2007) they concluded that not all existing published primers available in literature were competent under South African environmental conditions. All the primers used in this study showed that they were competent under South African environmental conditions and were existing primers that were designed to amplify gene fragments that included a consensus sequence for a characteristic domain (nonribosomal peptide sythetase operon and polyketide synthase operon) plus regions flanking that sequence (Dittmann et al., 1997; Nishizawa et al., 1999, 2000; Tillett et al., 2000, 2001). The outcome of the PCR products confirms the occurrence of various mcy genes in the $M$. aeruginosa strains isolated from the Nhanganzwane Dam in 2007 that could be correlated with their ability to synthesize microcystins (Hui et al., 2002).

\section{Conclusion}

In the Kruger National Park setting we found that conditions which favor the excessive cyanobacterial growth such as the abnormal high winter temperatures, high levels of nutrients in the water caused by defecation and urination of a relatively large resident hippopotamus population as well as stagnant water all played a role in the development of the toxic cyanobacterial bloom that occurred in the Nhanganzwane Dam. Under such conditions, artificial dams in the Kruger National Park need to be monitored in order to predict these biotoxicity events. The present study also shows that existing reliable and simple PCR methodology can be used for the rapid screening of the presence of genotoxic strains in artificial water points in conservation areas. Monitoring by PCR methodology could be used as a proactive hazard identification technique to alert animal health professionals and wildlife managers to improve their preparedness and assist in the management of toxic Microcystis bloom events, as was experienced in the case of the Nhlanganzwane Dam.

\section{Acknowledgments}

The authors express their sincere gratitude to the South African Weather Bureau for providing meteorological data. We also would like to thank the National Research Foundation for provision of funding and the two unknown referees for critically reviewing the manuscript and suggesting useful changes.

\section{References}

American Public Health Association, American Water Works Association and Water Environment Association, 1998. Standard Methods for the Examination of Water and Wastewater, 20th ed. American Public Health Association, Washington, DC

Bengis, R.G., Govender, D., Keet, D.F., 2008. Multi-species mortality events related to cyanobacterial bio-intoxication in the Kruger National Park. In: Proceedings 
of the Forth South African Veterinary and Para-Veterinary Conference, Sun City, South Africa, 7-11 July 2008, pp. 1-3.

Benndorf, J., Henning, M., 1989. Daphnia and toxic blooms of Microcystis aeruginosa in Bautzen Reservoir (GDR). Int. Rev. Gesamt. Hydrobiol. 74, 233-248.

Bolch, C.J.S., Blackburn, S.I., Jones, G.J., Orr, P.T., Crewe, P.M., 1997. Plasmid content and distribution in the toxic cyanobacterial genus Microcystis Kützing ex Lemmermann (Cyanobacteria: Chroococcales). Phycology 36, 6-11.

Bonnet, M.P., Poulin, M., 2002. Numerical modeling of the planktonic succession in a nutrient-rich reservoir: environmental and physiological factors leading to Microcystis aeruginosa dominance. Ecol. Model. 156, 93-112.

Bomchul, K., Park, J.-H., Hwang, G., Jun, M.-S., Choi, K., 2001. Eutrophication of reservoirs in South Korea. Limnology 2, 223-229.

Botha, A.-M., Oberholster, P.J., 2007. PCR based markers for detection and identification of toxic cyanobacteria. Water Research Commission Report No. K5/1502/01/07, Pretoria, ZA.

Dittmann, E., Neilan, B.A., Erhard, M., von Döhren, H., Börner, T. 1997. Insertional mutagenesis of a peptide synthetase gene that is responsible for hepatotoxin production in the cyanobacterium Microcystis aeruginosa PCC7806. Mol. Microbiol. 26, 779-787.

Dokulil, M.T., Teubner, K., 2000. Cyanobacterial dominance in lakes. Hydrobiology $438,1-12$

Eckhardt, H.C., van Wilgen, B.W., Biggs, H.C., 2000. Trens in woody vegetation cover in the Kruger National Park, South Africa, between 1940-1998. Afr. J. Ecol. 38, $108-115$.

Falconer, I., Burch, M., Steffensen, D., Choice, M., Coverdale, O., 1994. Toxicity of the blue-green alga (cyanobacterium) Microcystis aeruginosa in drinking water to growing pigs, as an animal model for human injury and risk assessment. J. Environ. Toxicol. Water Qual. 9, 131-139.

Fawell, J.K., James, C.P., James, H.A., 1994. Toxin from blue green algae: toxicological assessment of microcystin-LR and a method for its determination in water. Report No. FR 0359/2/DoE 3358/2. Foundation of Water Research, Marlow, UK, pp. $1-46$.

Farwell, J.K., Mitchell, R.E., Everett, D.J., Hill, R.E., 1999. The toxicity of cyanobacterial toxins in the mouse: I. Microcystin-LR. Hum. Exp. Toxicol. 18, 162-167.

Foose, T., 1982. Trophic strategies of ruminant versus nonruminant ungulates. Ph.D. Dissertation, University of Chicago, Chicago.

Forsberg, C., Ryding, S.O., 1980. Eutrophication parameters and trophic state indices in 30 Swedish waste-receiving lakes. Arch. Hydrobiol. 89, 189-207.

Gaylard, A., Owen-Smith, N., Redfern, J.F., 2003. Surface water availability: implications for heterogeneity and ecosystem processes. In: du Toit, J.T., Rogers, K.H., Biggs, H.C. (Eds.), The Kruger Experience: Ecology and Management of Savanna Heterogeneity. Island Press, Washington, pp. 171-188.

Harada, K.-I., Kondo, F., Lawton, L., 1996. Laboratory analysis of cyanotoxins. In: Chorus, I., Bartram, J. (Eds.), Toxic Cyanobacteria in Water: A Guide to Their Public Health Consequences, Monitoring and Management. E \& FN Spon, London, UK, pp. 369-405.

Hui, P., Song, L., Lui, Y., Börner, T., 2002. Detection of hepatotoxic Microcystis strains by PCR with intact cells from both culture and environmental samples. Arch. Microbiol. 178, 421-427.

Kromkamp, J.C., Mur, L.R., 1984. Buoyant density changes in the cyanobacterium Microcystis aeruginosa due to changes in the cellular carbohydrate content. FEMS Microbiol. Lett. 25, 105-109.

Kurmayer, R., Christiansen, G., Chorus, I., 2003. The abundance of microcystinproducing genotypes correlates positively with colony size in Microcystis sp. and determines its microcystin net production in Lake Wannsee. Appl. Environ. Microbiol. 69, 787-795.

Laws, R.M., 1968. Dentition and ageing in the hippopotamus. E. Afr. Wildl. J. 6, $19-52$.

Lund, J.W.G., Kipling, C., Le Cren, E.O., 1958. The inverted microscope method of estimating algal numbers and the statistical basis of estimations by counting. Hydrobiology 11, 143-170.

Lopez Rodas, V., Costas, E., 1999. Preference of mice to consume Microcystis aeruginosa (toxin-producing cyanobacteria): a possible explanation for numerous fatalities of livestock and wildlife. Res. Vet. Sci. 67, 107-110.

Meissner, K., Dittmann, E., Börner, T., 1996. Toxic and non-toxic strains of the cyanobacterium Microcystis aeruginosa contain sequences homologous to peptide synthetase genes. FEMS Micro. Lett. 135, 295-303.

Meyer, J.A., Casey, N.H., du Toit, J.G., 1996. Game ranch planning Part 3. In: Bothma, J.P. (Ed.), Game Ranch Management. JL van Scaik Publishers, South Africa, pp. 95-99.

Mole, J., Chow, C., Burch, M., Drikas, M., 1997. In: Proceedings of the 13th Australasian Society for Phycology and Aquatic Botany Annual Conference, Hobart, Tasmania.

Nishizawa, T., Ueda, A., Asayama, M., Fujii, K., Harada, K., Ochi, K., Shirai, K., 2000. Polyketide synthase gene coupled to the peptide synthetase module involved in the biosynthesis of the cyclic heptapeptide microcystin. J. Biochem. (Tokyo) $127,779-789$.
Nishizawa, T., Fujii, M., Harada, K., Shirai, M., 1999. Genetic analysis of the peptide synthetase genes for a cyclic heptapeptide microcystin in Microcystis spp. J. Biochem. (Tokyo) 126, 520-529.

Oberholster, P.J., Botha, A.-M., Cloete, T.E., 2005. An overview of toxic freshwater cyanobacteria in South Africa with special reference to risk, impact and detection by molecular marker tools. Biokemistri 17, 57-71.

Oberholster, P.J., Botha, A.-M., Cloete, T.E., 2006. Toxic cyanobacterial blooms in a shallow, artificially mixed urban lake in Colorado, USA. Lakes Reservoirs: Res. Manage. 11, 111-123.

Oberholster, PJ. Botha, A.-M., 2007. Use of PCR based technologies for risk assessment of a winter cyanobacterial bloom in Lake Midmar, South Africa. Afr J. Biotechnol. 6, 14-21.

Orr, P.T., Jones, G.J., 1998. Relationship between microcystin production and cell division rates in nitrogen-limited Microcystis aeruginosa cultures. Limnol. Oceanogr. 43, 1604-1614.

Owen-Smith, N., 1988. Megaherbivores. The Influence of Very Large Body Size on Ecology. Cambridge University Press, Cambridge.

Owen-Smith, N., 1973. The behavioral ecology of the white rhinoceros. Ph.D. Thesis, University of Wisconsin, Wisconsin.

Padisak, J., 1993. Microscopic examination of phytoplankton samples. In: Proceedings of the International Training Course on Limnological Bases of Lake Management, 24 May-5 June 1993, Tihany, Hungary.

Pearson, M.J., 1990. Toxic blue-green algae. Report of the National Rivers Authority. Water Quality Series No. 2. National River Authority, London, UK.

Pienaar, U.deV., 1970. Water resources of the Kruger National Park. Afr. Wildl. 24 180-191.

Pitois, S., Jackson, M.H., Wood, B.J.B., 2001. Sources of the Eutrophication problems associated with toxic algae: an overview. J. Environ. Health 64, 25-30.

Porra, R.J., Thompson, W.A., Kriedemann, P.E., 1989. Determination of accurate extinction coefficient and simultaneous equations for assaying chlorophyll $a$ and $b$ extracted with four different solvents: verification of the concentration of chlorophyll standards by atomic absorption spectrometry. Biochim. Biophys. Acta 975, 384-394.

Quahid, Y., Sanz-Alferez, S., Perez-Silva, G., del Campo, F.F., 2004. Cyanobacteria and microcystin monitorization of Pinilla Reservoir (Madrid). Abstract Book of IV Iberian Conference of Limnology, Porto, pp. 44-45.

Quahid, Y., Perez-Silva, G., del Campo, F.F., 2005. Identification of potentially toxic environmental Microcystis by individual and multiple PCR amplification of specific microcystin synthetase gene regions. Environ. Toxicol. 20, 235-242.

Rast, W., Thornton, J.A., 1996. Trends in eutrophication research and control. Hydro. Proc. 10, 295-313.

Robarts, R.D., Zohary, T., 1992. The influence of temperature and light on the upper limit of Microcystis aeruginosa production in a hypertrophic reservoir. J. Plank Res. 14, 235-247.

Schwarm, A., Clauss, M., Flach, E.J., 2003. Passage rate and digestibility coefficients in captive hippopotamidae, a pilot study. Verhandlungsber. Erkrank. Zootiere $41,413-418$.

SPSS Inc., 1997. Systat 7.0.1 for Windows: Statistics. SPSS Inc., Chicago, IL.

Spencer, C.N., King, D.L., 1987. Regulation of blue-green algal buoyancy and bloom formation by light, inorganic nitrogen, $\mathrm{CO}_{2}$, and trophic level interactions. Hydrobiology 144, 183-192.

Tillett, D., Parker, D.L., Neilan, B.A., 2001. Detection of toxigenicity by a probe for the microcystin synthetase A gene $(m c y A)$ of the cyanobacterial genus Microcystis: comparison of toxicities with 16S rRNA and phycocyanin operon (Phycocyanin Intergenic Spacer) phylogenies. Appl. Environ. Microbiol. 67, $2810-2818$.

Tillett, D., Dittmann, E., Erhard, M., von Döhren, H., Börner, T., Neilan, B.A., 2000 Structural organization of microcystin biosynthesis in Microcystis aeruginosa PCC7806: an integrated peptidepolyketide synthetase system. Chem. Biol. 7, 753-764.

Van der Westhuizen, A.J., Eloff, J.N., 1985. Effect of temperature and light on the toxicity and growth of the bluegreen alga Microcystis aeruginosa (UV-006). Planta 163, 55-59.

Van Ginkel, C.E., 2004. A national survey of the incidence of cyanobacterial blooms and toxin production in major impoundments. Internal Report No. N/0000/00/ DEQ/0503, Resource Quality Services, Department of Water Affairs and Forestry, Pretoria, South Africa, pp. 1-44.

Visser, P.M., Ibelings, B.W., Van der Veer, B., Koedood, J., Mur, L.R., 1996. Artificial mixing prevents nuisance blooms of the cyanobacterium Microcystis in Lake Nieuwe Meer, The Netherlands. Fresh Biol. 36, 435-450.

Vollenweider, R.A., 1968. Scientific fundamentals of the eutrophication of lakes and flowing waters, with particular reference to nitrogen and phosphorus as factors in eutrophication. Technical Report DAS/CSI/68.27. Paris: Org. for Econ. Cooperation and Dev.

Wasson, R., Banens, R., Davies, P., Maher, W., Robinson, S., Volker, R., Tait, D., Watson-Brown, S., 1996. Inland waters. In: Taylor, R. (Ed.), Australia: State of the Environment. Commonwealth Scientific and Industrial Research Organization, Collingwood, Australia, pp. 7.1-7.55.

Wehr, J.D., Sheath, R.G., 2003. Freshwater Algae of North America: Ecology and Classification. Academic Press, Massachusetts, USA, pp. 1-834. 